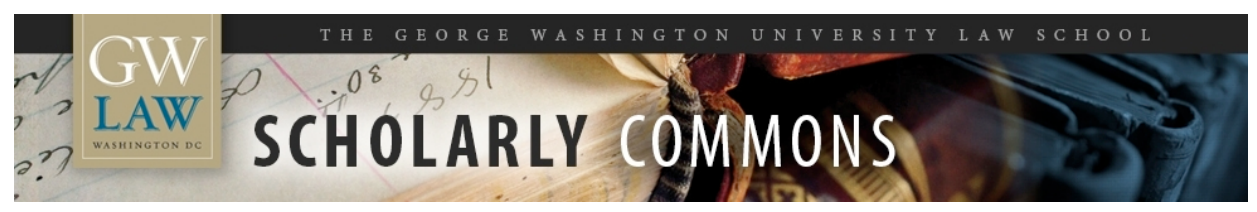

\title{
Historic Preservation Grants to Houses of Worship: A Case Study in the Survival of Separationism
}

Ira C. Lupu

George Washington University Law School

Robert W. Tuttle

George Washington University Law School

Follow this and additional works at: https://scholarship.law.gwu.edu/faculty_publications

Part of the Law Commons

\section{Recommended Citation}

Ira C. Lupu \& Robert W. Tuttle, Historic Preservation Grants to Houses of Worship: A Case Study in the Survival of Separationism, 43 B.C. L. Rev. (2002).

This Article is brought to you for free and open access by the Faculty Scholarship at Scholarly Commons. It has been accepted for inclusion in GW Law Faculty Publications \& Other Works by an authorized administrator of Scholarly Commons. For more information, please contact spagel@law.gwu.edu. 


\section{HISTORIC PRESERVATION GRANTS TO HOUSES OF WORSHIP: A CASE STUDY IN THE SURVIVAL OF SEPARATIONISM}

(forthcoming, 2002, in Symposium, Shifting Into Neutral? Emerging Perspectives on the Separation of Church and State, Boston College Law Review)

Ira C. Lupu and Robert W. Tuttle ${ }^{1}$

The relationship between government and places of worship presents questions as old as the Republic. Although these questions arise in many contexts, ${ }^{2}$ our primary focus is on the problem of historic preservation. Courts have decided a number of important cases about the rights of religious institutions to resist historical landmarking and the strict governmental

${ }^{1}$ Copyright, 2002, Ira C. Lupu \& Robert W. Tuttle. Ira C. Lupu is the Louis Harkey Mayo Research Professor of Law at George Washington University Law School; Robert Tuttle is an Associate Professor of Law at George Washington University Law School. The authors are the co-directors of the Legal Tracking Project of the Roundtable on Religion and Social Welfare, sponsored by the Pew Charitable Trusts. The opinions in the Article are those of the authors, and do not necessarily reflect the views of the Pew Charitable Trust. Our thanks to for helpful comments on an earlier version of this paper, to the many federal and state historic preservation officials who provided us with helpful information, and to Joann Corey and Brian Miklos for invaluable research assistance.

${ }^{2}$ These include the resolution of factional disputes within faith communities over the ownership and control of property, see generally C. Kent Greenawalt, Hands Off! Civil Court Involvement in Conflicts Over Religious Property, 98 Colum. L. Rev. 1843 (1998); zoning decisions concerning land use by religious institutions, see generally Robert W. Tuttle, How Firm a Foundation? Protecting Religious Land Uses After Boerne, 68 George Washington L. Rev. 861 (2000); emergency assistance to religious property that has been damaged in disasters, see text at notes 92-93 infra; government certification of the tax-exempt character of bonds whose proceeds will be used for construction of buildings with some religious character, see text at text at note 42 infra. 
controls over property that accompany that status. ${ }^{3}$ Indeed, City of Boerne v. Flores, ${ }^{4}$ the case in which the U.S. Supreme Court invalidated the Religious Freedom Restoration Act as applied to the states, arose in the context of precisely such a dispute.

Our attention, however, will be on the expenditure side of the historic preservation question - to what extent may the state make grants and loans to assist in the historic preservation of buildings which are under coercive preservation regimes, and which are devoted to religious use $?^{5}$ To our knowledge, there are no judicial decisions on this subject, ${ }^{6}$ although state administrative officers face the question regularly. True Separationists oppose both the landmarking of worship sites, and the payment of grants to owners of these sites if they are so landmarked, while committed Neutralists favor both the regulation and support of houses of worship for historic preservation to precisely the same extent as other structures. ${ }^{7}$ And there of

3 See, e.g., St. Bartholomew's Church v. City of New York, 914 F.2d 348 (1990); First Covenant Church v. Seattle, 840 P.2d 774 (Wash. 1992); Society of Jesus of New England v. Boston Landmarks Commission, 409 Mass. 38, 564 N.E.2d 571 (1990); East Bay Asian Local Development Corp. v. California, 13 P.3d 1122 (Ca. 2000), cert. denied, 121 S. Ct. 1735 (2001). We discuss these cases in Part IIIA., infra.

${ }^{4} 521$ U.S. 507 (1997).

5 The only secondary materials we have located on this subject are Louis R. Cohen, Religious Freedoms: Historic Preservation Grants and the Establishment Clause, ALI-ABA Course of Study Materials: Historic Preservation Law (October 2001); Dina A. Keever, Note, Public Funds and the Historical Preservation of Churches: Preserving History or Advancing Religion?, 21 Fla. St. U.L. Rev. 1327 (1994).

${ }^{6}$ The one that comes closest is Frohliger v Richardson, 63 Cal. App. 209, 218 P 497 (Cal. Ct. App. $1^{\text {st }}$ Dist. 1923), a 1923 decision of the California Supreme Court on the permissibility of state financial support for preserving the San Diego mission. That case did not involve the prospect of a coercive regulatory regime, pursuant to which the mission's owners would have obligations to preserve the structure unchanged, being imposed upon the mission.

${ }^{7}$ We develop at length the concepts of Separationism and Neutralism in Ira C. Lupu \& Robert W. Tuttle, The Distinctive Place of Religious Entities in Our Constitutional Order, 47 Vill. L. Rev. 37 (2002) (hereafter, "Distinctive Place"). 
course may be other, less symmetrical formulations that should be open for consideration. ${ }^{8}$

The paper will proceed as follows. Part I will highlight themes in the historical and judicial legacy of American Separationism, particularly as they apply to expenditures in support of the physical structures of religious entities. Part II will sketch the rise of the Neutrality principle and the decline - still incomplete - of the Separationist paradigm over the past twenty years. The paper's centerpiece, Part III, turns to the particulars of historic preservation. Part IIIA. addresses the struggle over the question of regulatory exemptions, for structures devoted to religious use, from historic preservation laws. Part IIIB. introduces an intriguing pair of dueling legal opinions, from prominent executive branch lawyers, on the question of the constitutional permissibility of government grants for historic preservation of religious structures. Part IIIC. describes in detail the current patterns, policies, and practices of government, federal and state, with respect to financial support for historic preservation of such structures, and contrasts these patterns of financial support with those currently in place in other government programs in which government may support financially the physical structures owned by religious entities. Finally, Part IV will appraise the details unpacked earlier in light of the larger, contemporary struggle between Separationism and Neutralism to become the dominant Religion Clause paradigm.

${ }^{8}$ Those whom we call Religionists, see Distinctive Place, note 7 supra, at 48 , systematically favor whatever will help religious institutions; in this context, that would involve preservation grants for religious institutions without preservation regulations and orders. Those whom we call Secularists, see id. at 48-49, systematically disfavor whatever would help such institutions; here, that would involve making them subject to coercive regulation while barring them from grants. We do not think a principled account of the Religion Clauses can be attached to either of these views. As we explain in more detail at text at notes 43-45 infra, we believe that Religion Clause symmetry - pursuant to which constitutional limits on government interference with religion map precisely onto the limits of government sponsorship of religion - is a necessary condition of a persuasive account of the Religion Clauses. 


\section{Government Support for Religious Structures - The Separationist Legacy}

As all students of Religion Clause history know, James Madison's Memorial and Remonstrance Against Religious Assessments ${ }^{9}$ is the most important statement about the American attitude toward church-state relations in the early days of the Republic. Its publication in 1784, and its success in turning the political tide in Virginia just three years before the Philadelphia Convention from which the new federal Constitution was to emerge, marked a tectonic shift in the structure of argumentation in America on state support for religion. ${ }^{10}$ The Memorial and Remonstrance had as its target a particular religious assessment bill, which was designed to appropriate money for Christian sects in Virginia. Each of those sects, upon receiving the funds allocated to it by taxpayer designation, would have been obliged to spend them on "a provision for a Minister or Teacher of the Gospel . . . or to providing places of divine worship." 11 Madison's objections to the bill won the day; it was defeated, and in its stead the Virginia Assembly enacted Jefferson's Bill for Religious Liberty, which provided in part "[t]hat no man shall be compelled to ... support any religious worship, place, or ministry whatsoever . . , 12

${ }^{9}$ The Memorial \& Remonstrance is set out as an Appendix to Justice Rutledge's dissent in Everson v. Ewing Township, 330 U.S. 1, 63-72 (1947).

${ }^{10}$ The primary contribution of the Memorial \& Remonstrance was its focus on the advantages to government, as well as to religion, that would ensue from extensive church-state separation. For a thorough analysis of the distinctive contribution of the Memorial \& Remonstrance and an analysis of the ways its lessons might inform the contemporary debate about school vouchers, see Vincent Blasi, School Vouchers and Religious Liberty: Seven Questions from Madison's Memorial \& Remonstrance, 87 Corn. L. Rev. xx (2002).

${ }^{11}$ Id. at 74 (Rutledge, J., dissenting). The proposed assessment bill permitted Quakers and Mennonites to promote their mode of worship as they saw fit, presumably because neither sect had clergy or houses of worship.

${ }^{12}$ Id. at 13. 
There is of course considerable debate over the extent to which this Virginia history should be taken as the measure of meaning for the Establishment Clause of the First Amendment. ${ }^{13}$ Whatever the right answer to that question may be, however, there can be no doubt that the Founding Generation saw compulsory taxation to pay for salary of clergy, and the construction of houses of worship, as a constitutional problem of the highest magnitude.

It would take more than one hundred years before the Supreme Court would confront issues of government financial support for physical structures associated with religious institutions. In Bradfield v. Roberts, ${ }^{14}$ decided in 1899, the Court rejected an Establishment Clause challenge to a federal appropriation for a hospital building, to be devoted exclusively to the medical care of those with contagious disease, at a medical facility controlled by the Roman Catholic Church. The Court focused on the building's purposes, not the identity of the owner, and ruled that the secularity of those purposes precluded the expenditure from being an establishment of religion.

Over seventy years later, at a moment of apex for the Separationist paradigm, the Supreme Court reaffirmed the principle of Bradfield in Tilton v. Richardson. ${ }^{15}$ Tilton upheld a series of federal construction grants, authorized by the Higher Education Facilities Act of 1963, to church-affiliated colleges and universities. The grants supported construction of libraries, a language laboratory, and buildings for science, and music and art. The Act expressly excluded "any facility used or to be used for sectarian instruction or as a place for religious worship, or ... any facility which ... is used or to be used primarily in connection with any part of the program

\footnotetext{
${ }^{13}$ See, e.g., Wallace v. Jaffree, 472 U.S. 38, xx (1985) (Rehnquist, J., dissenting).

${ }^{14} 175$ U.S. 291 (1899).

${ }^{15} 403$ U.S. 672 (1971). The Court decided Tilton on the same day in 1971 as Lemon v.
} Kurtzman, 403 U.S. 602 (1971). 
of a school or department of divinity ... “ A four-Justice plurality, augmented by Justice White's concurrence, concluded that the statute authorized, and the Constitution did not forbid, grants to church-affiliated institutions. The constitutional reasoning of the plurality depended heavily on the fact that the schools that had received the grants had not been shown to be "pervasively sectarian" and had maintained the federally supported buildings in a scrupulously secular fashion. Moreover, the plurality concluded that the monitoring required to insure that the schools complied with the secular use restrictions would not lead to forbidden entanglements between the state and religiously affiliated institutions. ${ }^{16}$

The Court in Tilton was unanimous, however, in striking down one portion of the federal scheme. As originally enacted, the program had limited to twenty years the "secular use" restriction on federally subsidized buildings. The expiration of the twenty-year period would have permitted the school to make sectarian uses of the building, and this, everyone on the Court agreed ${ }^{17}$ would involve the government in impermissibly advancing religion. Accordingly, the Court held that the restriction must, by force of constitutional requirement, extend for the life of the building.

A few years later, in Hunt v. McNair, ${ }^{18}$ the Court extended the "secular use" principle of Bradfield and Tilton to actions of a state issuing revenue bonds, as part of a religion-neutral program, for the purpose of financing capital improvements at the Baptist College of Charleston. As in Tilton, the program included explicit restrictions on the use of bond-financed structures; all

${ }^{16}$ In Lemon, by contrast, the Court found that the pervasively sectarian character of most of the aided elementary and secondary schools made it impossible to monitor the secularity of the expenditures without the entanglement becoming constitutionally excessive. Id. at xxx.

${ }^{17} 403$ U.S. at xxx (plurality); xxx (White, J., concurring); xxx (Black, Marshall, and Douglas, dissenting); and xxx (Brennan, J., dissenting).

${ }^{18} 413$ U.S. 734 (1973). 
uses for sectarian instruction or worship were forbidden. Moreover, the bond scheme did not involve any direct transfer of government funds to the aided institution. The funds all came from private investors, assured of tax-favorable treatment by the state's participation in the scheme. In a 6-3 ruling, the Court held that such a scheme did not have the purpose or primary effect of advancing religion, nor did it involve the state in excessive monitoring of the religious affairs of the school.

Bradfield, Tilton, and Hunt all approved of state support for secular uses of wholly secular structures at religiously controlled institutions. None of the three, however, involved the question of permissibility of state support for buildings devoted to worship and sectarian teaching. With respect to that question, which resides in greater proximity to the problem of the Virginia Assessment, there is but one key Supreme Court decision - Committee for Public Education v. Nyquist, ${ }^{19}$ also decided in the midst of Separationism's fullest flowering.

These days, Nyquist is best known as the decision at the center of the controversy over school vouchers, ${ }^{20}$ because the case involved grants and so-called "tuition tax credits" for the benefit of parents whose children attended private schools, sectarian or otherwise. Another feature of the legislation invalidated in Nyquist, however, involved "maintenance and repair" grants to nonpublic schools, designed to aid them in the upkeep of their physical facilities. The

\footnotetext{
${ }^{19} 413$ U.S. 756 (1973).
}

${ }^{20}$ Simmons-Harris v. Zelman, 234 F.3d 945 (6 ${ }^{\text {th }}$ Cir. 2000), cert. granted Zelman v. Simmons-Harris, 533 U.S. 976 (2001). See id. at 953-54 (discussing Committee for Public Education v. Nyquist). The Nyquist decision also provides the central focus of a number of the briefs filed in the U.S. Supreme Court in the Zelman case. See, e.g., Brief for Respondents Doris Simmons-Harris, et.al., 2000 U.S. Briefs 1751 (invoking Nyquist as authority for upholding the decision of the lower courts). But see, e.g., Brief for the United States as Amicus Curiae Supporting Petitioners, 2000 US Briefs 1751, at*10 (distinguishing Nyquist and questioning its continued authority). For our views on Zelman, see Ira C. Lupu \& Robert W. Tuttle, Sites of Redemption: A Wide-Angle Look at Government Vouchers and Sectarian Service Providers, xx J. Law \& Politics xx, in Symposium, The End of Separatism (forthcoming, 2002). 
state calculated the amount of these grants on a per pupil basis, subject to a maximum based upon comparable expenditures in the public school system, and did not impose any "secular use" restriction upon the grants.

By a vote of $8-1,{ }^{21}$ the Supreme Court struck down the grants for "maintenance and repair." The central portion of its discussion is as follows: ${ }^{22}$

No attempt is made to restrict payments to those expenditures used exclusively for secular purposes, nor do we think it possible within the context of these religion-oriented institutions to impose such restrictions. Nothing in the statute, for instance, bars a qualifying school from paying out of state funds the salaries of employees who maintain the school chapel, or the cost of renovating classrooms in which religion is taught, or the cost of heating and lighting those same facilities. Absent appropriate restrictions on [such] expenditures, it simply cannot be denied that [these grants have] a primary effect that advances religion in that [they] subsidize[] directly the religious activities of sectarian elementary and secondary schools.

Moreover, after invoking that portion of Tilton v. Richardson which invalidated the complete reversion of federally financed buildings, after twenty years, to the unrestricted use of religiously affiliated colleges, the Nyquist Court concluded this portion of its opinion with a categorical assertion that hearkened back to the controversy over the Virginia Assessment. "If the State may not erect buildings in which religious activities are to take place," Justice Powell wrote, "it may not maintain such buildings or renovate them when they fall into disrepair."23

Nyquist thus stands as the singular and unchallenged Supreme Court precedent on the issue of state support for structures whose uses include worship or religious instruction. Among its central premises, of course, is that religious elementary and secondary schools are likely to be

${ }^{21}$ Only Justice White dissented from this portion of the Court's opinion, and he did so with virtually no elaboration of his reasons. Id. at 820 .

${ }^{22}$ Id. at 774.

${ }^{23}$ Id. at 777 (citing, inter alia, Everson v. Ewing Township, 330 U.S. 1, 11 (1947): “The imposition of taxes to pay ministers' salaries and to build and maintain churches and and church property aroused their indignation. It was these feelings which found expression in [the Establishment Clause of] the First Amendment."). 
"pervasively sectarian," so that any unrestricted transfers to their operations will have a forbidden "primary effect" of advancing religion. However controversial it may be today to categorize such schools in this way,$^{24}$ there can be little doubt of the sectarian character of buildings devoted exclusively to worship. If such structures are constitutionally distinctive, as the Court in Nyquist assumed and as our constitutional history appears to support, government grants to preserve them seem entirely impermissible.

\section{The Movement toward Neutralism}

In the Separationist world described in Part I, grants for the preservation of structures devoted to worship would seem impossible to sustain constitutionally. Over the past twenty years, however, the grip of Separationism on the law of the Religion Clauses has declined, and the paradigm of Neutralism has ascended. Has this trend changed the landscape sufficiently to warrant a different outcome on the permissibility of such grants?

The shift to Neutralism has had three major components, only one of which bears directly on the issue of historic preservation grants. First, for the past twenty years, the Supreme Court has been vigorously enforcing rights of equal access to various public fora for religious causes and speakers. This line of cases, starting with Widmar $\mathrm{v}$. Vincent ${ }^{25}$ and running through the Good News Club $^{26}$ decision in 2001, represents a repudiation of an extreme version of

\footnotetext{
${ }^{24}$ The opinions in Mitchell v. Helms, 530 U.S. 793 (2000), cast substantial doubt on the continuing vitality of the idea that "pervasively sectarian" are under special disabilities in the receipt of government benefits. A 4-Justice plurality in Mitchell explicitly repudiates the concept, id. at xxx, and the concurring opinion by Justice O'Connor, joined by Justice Breyer, id. at Xxx, does not rely upon it and reaches a result inconsistent with it. See also Maryland Higher Educ. Ass'n v. Columbia Union College, 527 U.S. 1013 (Thomas, J., dissenting from denial of certiorari, and arguing for reconsideration of the concept of "pervasively sectarian" institutions).

${ }^{25} 454$ U.S. 263 (1981).

${ }^{26}$ Good News Club v. Milford Central School, 121 S. Ct. 2093 (2001). See also Lamb's Chapel v. Center Moriches Union Free School Dist., 508 U.S. 384 (1993); Rosenberger v. Rector
} 
Separationism, pursuant to which private religious speech is compulsorily excluded from publicly controlled space. This entire development arose out of the overreaction of local officials to the School Prayer Cases ${ }^{27}$ although those decisions had involved only situations of officially sponsored worship in public schools, some local governments had erroneously extended the concerns of the School Prayer Cases to wholly private speech in public settings. Nevertheless, the recent decisions involving prayer at public school sporting events ${ }^{28}$ and commencements, ${ }^{29}$ when measured against the backdrop of the equal access decisions of the past two decades, demonstrate that Neutralism extends to private speech in public fora but does NOT extend to government sponsored speech. ${ }^{30}$ When government speaks, or private parties speak in contexts in which the message is attributable to the government, some version of Separationism still controls. $^{31}$

The second major development in the direction of Neutralism appeared in 1990, in the

\& Visitors of the Univ. of Virginia, 515 U.S. 819 (1995). (1962).

${ }^{27}$ Abington Sch. Dist. v. Schemmp, 374 U.S. 203 (1963); Engel v. Vitale, 370 U.S. 421

${ }^{28}$ Santa Fe Ind. Sch. Dist v. Doe, 530 U.S. 290 (2000).

${ }^{29}$ Lee v. Weisman, 505 U.S. 577 (1992).

${ }^{30}$ This proposition is true outside of public schools as well as inside of them. The entire question of impermissible government "endorsement" of religion is bound up with the idea that the state may not be neutral between religious and nonreligious messages when government speaks. Compare Allegheny County v. ACLU, 492 U.S. 573 (1989) with Capitol Square Review and Advisory Board v. Pinette, 515 U.S. 753 (1995).

${ }^{31}$ See Santa Fe. Ind. Sch. Dist. v. Doe, 530 U.S. 290 (2000) (public school may not sponsor student-uttered prayer over public address system at high school football game). For an important recent effort to grapple with the problem of religious utterances by students in various public school contexts, see Kathleen A. Brady, The Push to Private Religious Expression: Are We Missing Something?, 70 Fordham L. Rev. 1147 (2002). 
form of the Supreme Court's surprisingly broad decision in Employment Division v. Smith. ${ }^{32}$

Smith held that courts should no longer apply the compelling interest test to claims of exemption, based upon the Free Exercise Clause, from religion-neutral, general laws. Although the preSmith law had not been nearly so religion-friendly as the opponents of Smith would have us believe, ${ }^{33}$ the rhetorical structure of Free Exercise doctrine had indeed been marked by a Separationist character; prior to Smith, claims that general legal norms burdened religiously motivated choices triggered an inquiry that was not similarly triggered by burdens on choices motivated by nonreligious reasons. Smith's Neutralist move, therefore, was to remit religionbased claims against general laws to precisely the same status as claims based on other reasons for desiring to be free of such laws. If such laws violated other constitutional protections - free speech, or privacy, for example - courts would strike them. If, however, the laws did not target religion by singling it out for disfavored treatment ${ }^{34}$ Free Exercise norms would not rescue religious adherents from the legal obligation to comply. Smith of course bears heavily on the question of exemption of religious institutions from the regulatory regime associated with historic preservation laws, but does not speak to the issue of the constitutionality of historic preservation grants to such institutions.

The third, and for our purposes most relevant, shift in the direction of Neutralism arises from recent cases involving government assistance to private schools, including sectarian ones.

32494 U.S. 872 (1990).

${ }^{33}$ Ira C. Lupu, Of Time and the RFRA: A Lawyer's Guide to the Religious Freedom Restoration Act, 56 Mont. L. Rev. 171, 176-185 (1995).

${ }^{34}$ For the rare but important case in which a particular sect had been so targeted, see Church of the Lukumi Babalu Aye, Inc. v. Hialeah, 508 U.S. 520 (1993). 
In Agostini v. Felton, ${ }^{35}$ decided in 1997, and in Mitchell v. Helms,${ }^{36}$ decided in 2000, the Supreme Court effectively repudiated the concept that all assistance to "pervasively sectarian" institutions was constitutionally forbidden. Agostini upheld the inclusion of sectarian schools in a federal program which provided remedial instruction, by teachers who are public employees, to students attending schools in educationally deprived areas. ${ }^{37}$ Mitchell, which also involved a religion-neutral federal program, upheld the transfer of educational materials and equipment, including computer hardware and software, to sectarian schools. In both Agostini and Mitchell, the statute required that the goods and services transferred be limited to those of a secular character.

The Court plurality in Mitchell went furthest in its rejection of the doctrinal trappings and underlying premises of Separationism. It explicitly discarded the notion of "pervasive sectarianism, ${ }^{938}$ condemning it as anti-Catholic in its origins, disturbing in the incentives it created for religious entities to dilute their faith, and unconstitutionally intrusive in the structure of adjudication it produced. Moreover, the Mitchell plurality made the full plunge toward Establishment Clause Neutralism in cases in which government transfers are challenged; so long as the category of aided institutions is religion-neutral, and the aided program does not result in religious indoctrination for which government is responsible, the Mitchell plurality would permit transfers to a broad category of nonprofit institutions, including the most sectarian among them.

35521 U.S. 203 (1997), overruling Aguilar v. Felton, 473 U.S. 402 (1985)..

${ }^{36} 530$ U.S. 793 (2000).

${ }^{37}$ Perhaps because public employees were doing the teaching, the Court in Agostini was not concerned that the remedial program supported sectarian instruction, though the remedial program indeed benefitted schools that seemed to fit earlier descriptions of "pervasively sectarian institutions."

${ }^{38}$ Mitchell, 530 U.S. at xxx (plurality opinion). 
One would think, therefore, that those in the Mitchell plurality would approve of historic preservation grants to houses of worship, so long as those eligible for grants were a larger, religion-neutral set of landmarked properties.

The Mitchell plurality drew the votes of four Justices. Three other members of the Court adhered to traditional Separationist views, and dissented in both cases, on the grounds that the aid schemes advanced religion, entangled the government with religion, or both. ${ }^{39}$ Justice O'Connor and Justice Breyer, however, concurring in Mitchell, took the view that neither the strong Neutralist view nor the strong Separationist view were constitutionally sound. The O'Connor-Breyer opinion did not defend the doctrine which excluded "pervasively sectarian" entities from state assistance, and in any event the results in Mitchell and Agostini cannot be squared with that doctrine. On the more refined question of precisely what sort of aid to sectarian entities is permissible, however, the O'Connor-Breyer view is that the Constitution forbids the use of such aid for religious instruction or activity. ${ }^{40}$

The O'Connor-Breyer approach, which permits aid to thoroughly sectarian institutions but not to their sectarian activities, for the moment controls the outcome in the Supreme Court. However plausible or correct their concurrence may be for programs of aid to sectarian schools, their view represents an incomplete shift from the paradigm of Separationism to that of Neutrality. Religious instruction, alone among subjects of pedagogy, remains off limits to government support. This rule, in turn, raises very difficult questions when the state assistance

${ }^{39}$ Agostini, 521 U.S. at xx (Souter, J., joined by Ginsburg \& Stevens, JJ., dissenting); Mitchell, 530 U.S. at xx (Souter, J., joined by Ginsburg \& Stevens, JJ., dissenting).

${ }^{40}$ The difficult question, of course, is how to distinguish and segregate religious from secular uses when the two are intertwined. Consider, for example, a class focused on reading skills that uses the Bible as its text. May the government regard that activity as secular, and pay for the Bibles and/or the costs of labor engaged in the instruction? 
takes the form of payment for bricks and mortar, or any other good which cannot be segregated into religious and secular components. ${ }^{41}$ May the state pay for the pro rata secular share of a building used for both secular and sectarian purposes? If not, should the question be framed in terms of the building's primary use? Or should religious uses that fairly could be called de minimis disqualify a structure from any and all government assistance in its maintenance and preservation? The shift, led by Justices O'Connor and Breyer, from an institutional focus to a more surgically precise activity-based focus, leaves such questions unanswered. ${ }^{42}$

\footnotetext{
${ }^{41}$ The recent announcement by Secretary Martinez of the U.S. Department of Housing and Urban Development that HUD is now willing to finance physical improvements of structures in which religious worship may accompany social services highlights the crucial relevance of the questions we address for charitable choice policy as well for issues of historic preservation. See Associated Press, Shelter told it can seek grant without dropping prayer, March 15, 2002 (describing a statement from Secretary Martinez that city officials may consider giving a federally financed community development grant for new doors, windows, and a new floor, to St. Francis House, a homeless shelter owned by the Catholic Diocese of Sioux Falls, SD, despite the fact that prayers are offered before the evening meal in the shelter)(AP J8542 rn sdsd-SDHomeless-Grant, Bjt, 0429) (copy on file with the authors); see also Tamara Lytle, Martinez Backs Homeless Shelter's Mealtime Prayers, The Orlando Sentinel, March 16, 2002, p. A1.

${ }^{42}$ The uncertainty inherent in the O'Connor-Breyer approach surfaces in two recent decisions, Steele v. Industrial Development Board (117 F.Supp.2d 693 (2000)) and Virginia College Building Authority v. Lynn (260 Va. 608, 538 S.E.2d 682 (2000)). Both cases involved the use of state revenue bonds to finance the construction of buildings owned by religious institutions, David Lipscomb University in Steele, and Regent University in Lynn. The financing schemes challenged in these two cases were indistinguishable from the one at issue in Hunt $v$. McNair (413 U.S. 734 (1973)); what differed was the nature of the universities benefitted by the program. In Steele and Lynn, each court found that the university in question was "pervasively sectarian" (Steele, 117 F.Supp.2d at 706-716; Lynn, 260 Va. at 623-24, 636-637). Both courts went on to say, however, that under Agostini, Mitchell, and other recent Supreme Court decisions the "pervasively sectarian" label proves neither dispositive nor irrelevant. The O'Connor-Breyer approach requires a closer analysis of the uses of the tax-supported funds (Steele, 117 F.Supp.2d at 706-07, 721-730; Lynn, 260 Va. at 637-639).

Despite this shared framework, the Steele and Lynn cases demonstrate the wide range of interpretations possible under the O'Connor-Breyer approach. In Steele, the court found that recent Establishment Clause decisions by the Supreme Court still require the presence of "safeguards implemented to ensure that the aid will support only the secular functions of the institutions" (Steele, 117 F.Supp.2d at 705). Although the loan agreement between Lipscomb University and the Industrial Development Board prohibited the University from using structures built with loan proceeds for sectarian worship or instruction (Id. at 727), this contractual
} 
As suggested by the inclusion of equal access claims, Free Exercise developments, and Establishment Clause decisions in our discussion of the trend from Separationism toward Neutralism, this movement is not narrowly clause-bound. These developments extend to matters involving state-imposed burdens upon religion as well as state-conferred benefits upon it; as such, they highlight the theme of symmetry between the Religion Clauses as a necessary element of any viable theory of religion's constitutional status. Full-fledged Neutralism, like some aggressive versions of Separationism, is indeed symmetrical, but both are marred by overstatement. ${ }^{43}$ Strong Separationism treats virtually all matters pertaining to state interaction

limitation fell short of minimum constitutional requirements in two ways. First, the Board delegated its enforcement power -- and the monitoring function presupposed by the enforcement power -- to the bank that provided the source of Lipscomb's loans, and then made exercise of that power discretionary (Id. at 728-729). Second, the actual use of loan funds indicated no effort to segregate their use from sectarian instruction. The loan proceeds were used to build and furnish a library dominated by religious literature, with a collection that focused heavily on the university's denomination. While the court found that the proportionate emphasis of the library itself suggested a failure to ensure the expenditure of funds on non-sectarian purposes, the problem was compounded by the availability of loan funds to purchase texts, including religious materials, for the library (Id. at 729-731). Because the Industrial Development Board failed to ensure that tax-supported funds would be used only for secular purposes, the court enjoined any further loans to Lipscomb University (Id. at 734-735).

In Lynn, however, the Virginia Supreme Court emphasized a different element of the O'Connor-Breyer approach, the status of "genuinely independent choices" of private actors in breaking the link between state programs and religious activities. Where government funds reach religious entities through free private choices, "endorsement of the religious message is reasonably attributed to the individuals who select the path of the aid," not the government (Mitchell v. Helms, 120 S. Ct. at 2559 (O'Connor, J. concurring), quoted in Virginia College Building Authority v. Lynn, 260 Va. 608, 639). Because the benefit of the bond program depended entirely on the decision of individual investors to purchase Regent University's bonds, and the bond program was available to a wide range of non-profit educational institutions, the Lynn court found no constitutional violation in a pervasively sectarian institution's participation in such a financing scheme (Lynn, $260 \mathrm{Va}$. at 638-639). The court went on to say, however, that Regent's proposed use of the bond funds for its Divinity School was impermissible, but not because of the Establishment Clause. Instead, such financing would violate the terms of the Virginia Educational Facilities Authority Act and the Virginia Constitution's Education Clause (Id. at 640).

\footnotetext{
${ }^{43}$ Much of our argument in Distinctive Place, note 7 supra, is devoted to exposing the inadequacies of asymmetrical versions of Separationism and Neutralism, and to explaining why
} 
with religion as constitutionally distinctive, while strong Neutralism tries to eradicate the legal distinctiveness of all such matters.

In our view, the constitutionally distinctive character of religion is real but limited, and derives from a theory of the secular state. The Religion Clauses mark a jurisdictional limitation on state power. The government is limited to temporal matters and may not intrude or otherwise assert its interest in the realm of the sacred ${ }^{44}$ a realm that includes worship practices. Government should not author, coerce, regulate, promote, or subsidize worship.

Armed with this substantive view of the boundary of state competence, we strongly believe that it should be applied symmetrically to both the Free Exercise Clause and the Establishment Clause. What the government may not regulate, it may not support financially, because financial support inevitably involves some measure of regulatory control. That the control accompanying state financial assistance may be seen as "voluntary" from the perspective of religious institutions should not alter the constitutionally required outcome. Because the boundaries required by the Establishment Clause are jurisdictional, not "rights-based," parties cannot waive them or in any other way consent to their removal. ${ }^{45}$

Symmetry of course works in both directions, defining the scope of the permissible as well as the forbidden. What the government may regulate, it may also subsidize. The precise content of the boundary between the secular, which should be open to both regulation and

symmetrical but overly muscular accounts of Separationism and Neutralism are unwise.

${ }^{44}$ See id. at 83-84. See also Carl Esbeck, Myths, Miscues, and Misconceptions: No-Aid Separationism and the Establishment Clause, XIII Notre Dame J. of Law, Ethics, \& Pub. Pol. 285, 292-300, 304-311 (1999) (analyzing the Establishment Clause as a restriction on government intrusion into "inherently religious matters.")

${ }^{45}$ For additional elaboration of the jurisdictional character of the Religion Clauses, see Carl Esbeck, The Establishment Clause as a Structural Restraint: Validations and Ramifications, in Symposium, The End of Separatism, xx J. of Law \& Politics xx (forthcoming 2002). 
support, and the religiously distinctive, which should be open to neither, must be worked out in particular legal contexts. The remainder of this piece seeks to illuminate that process of analysis and judgment in the context of historic preservation of houses of worship.

\section{Historic Preservation of Religious Structures}

The concepts of jurisdictional limitation and Religion Clause symmetry, developed at the end of Part II, will facilitate the discussion of the constitutional appropriateness of government grants for the historic preservation of houses of worship. In this Part III, we describe the extent to which houses of worship are exempt from the regulatory regimes which control landmarked structures, and proceed through a dramatic juxtaposition of dueling opinion letters from prominent public officials on the subject of preservation grants to houses of worship. We then describe the surprising array of policies and practices of governments, federal and state, with respect to such grants. We conclude in Part IV with suggestions about where to draw a substantively sound and Clause-symmetrical boundary between permissible and impermissible state involvement in the historic preservation of houses of worship.

\section{A. The Problem of Regulation}

Unsurprisingly, the process of government-mandated historic preservation of structures and neighborhoods has attracted a substantial amount of attention, ${ }^{46}$ especially as applied to

${ }^{46}$ At the federal level, comprehensive efforts to preserve historic structures and neighborhoods trace back to the National Historic Preservation Act, enacted in 1966, 16 U.S.C. $\S$ 470 et. seq. The Act established the National Register of Historic Places and created a mechanism for awarding grants to owners of historic properties and to state historic preservation offices. The Act did not, however, provide a legal basis for "landmarking" historic properties without their owners' consent. A number of states and localities, however, enacted more robust landmark statutes and ordinances, which permitted historic designation and regulation of properties even if owners of such properties objected. See generally, Daniel R. Mandelker, Land Use Law, $\S \S 11.22-11.34$ ( $3^{\text {rd }}$ ed. 1993). In Penn Central Transport. v. City of New York, 438 U.S. 104 (1978), the U.S. Supreme Court upheld a common version of these landmark ordinances against the owner's challenge under the Constitution's Takings Clause. 
structures owned by religious entities and used for worship. The process may be coercive, can create significant financial hardship, and, in the case of houses of worship, can limit the freedom of a religious community to expand its capability to hold worshipers; ${ }^{47}$ alter its structure for economic, $^{48}$ aesthetic, or liturgical ${ }^{49}$ reasons; or, in the most extreme case, reconfigure its interior worship space. $^{50}$

Courts have varied widely in their approaches to the questions raised by application of historic preservation ordinances to religious properties, and the issues have been complicated significantly by the decision in Smith, ${ }^{51}$ the enactment of the Religious Freedom Restoration

${ }^{47}$ City of Boerne v. Archbishop Flores, 521 U.S. 507 (1997). For discussion of the Boerne problem, see Colin Black, Comment, The Free Exercise Clause and Historic Preservation Law: Suggestions for a More Coherent Free Exercise Analysis, 72 Tul. L. Rev. 1767 (1998); Elizabeth C. Williamson, City of Boerne v. Flores and the Religious Freedom Restoration Act: The Delicate Balance Between Religious Freedom and Historic Preservation, 13 J. Land Use and Envtl. L. 107 (1997).

${ }^{48}$ See, e.g., St. Bartholomew’s Church v. City of New York, 914 F.2d 348 (1990). For commentary on the St. Bartholomew's decision, see Alan C. Weinstein, The Myth of Ministry vs. Mortar: A Legal and Policy Analysis of Landmark Designation of Religious Institutions, 65 Temp. L. Rev. 91 (1992).

${ }^{49}$ The possibility of liturgically-motivated alteration of the exterior of a house of worship is contemplated in the ordinance from which such structures were held exempt in First Covenant Church v. Seattle, 840 P.2d 774 (Wash. 1992).

${ }^{50}$ See Society of Jesus of New England v. Boston Landmarks Commission, 409 Mass. 38, 564 N.E.2d 571 (1990). For commentary inspired in part by this decision, see Angela Carmella, Houses of Worship and Religious Liberty: Constitutional Limits to Landmark Preservation and Architectural Review, 36 Vill. L. Rev. 401 (1991).

${ }^{51}$ Emp. Div. v. Smith, 494 U.S. 872 (1990). 
Act, ${ }^{52}$ its partial invalidation in City of Boerne, ${ }^{53}$ and the subsequent enactment of the Religious Land Use and Institutionalized Persons Act. ${ }^{54}$ In this space we can do more than summarize the major trends over the question of exemption from historic preservation ordinances for property devoted to religious uses. We believe, however, that a principled approach to the Religion Clauses requires symmetry between the Free Exercise question of exemption and the Establishment Clause question of disability to receive government support. Uncertainty with respect to the exemption question is, in our view, bound to give rise to corresponding uncertainty on the question of the permissibility of the grants.

For purposes of this paper, we think it will be most useful to categorize the existing approaches to exemption of religious institutions into four discrete models. The first, and broadest model, is that found in the California legislative exemption. By statute, California exempts all noncommercial property owned by religious corporations from the authority of local government to designate properties as historical landmarks. ${ }^{55}$ In East Bay Asian Local

${ }^{52}$ Religious Freedom Restoration Act, 42 U.S.C. $\S 2000 \mathrm{bb}$. See Keeler v. Mayor and City Council of Cumberland, 940 F. Supp. 879 (D. Md. 1996) (holding that RFRA is unconstitutional, and thus offers church no defense to landmark ordinance, but that application of landmark ordinance to the church still violated the church's free exercise of religion, because the landmark ordinance was not a "neutral law of general applicability.") Id. at 885-86.

${ }^{53}$ City of Boerne v. Archbishop Flores, 521 U.S. 507 (1997) (holding RFRA invalid as applied to the states).

${ }^{54}$ Religious Land Use and Institutionalized Persons Act, 42 U.S.C. $§ 2000 \mathrm{cc}$.

${ }^{55} \mathrm{Cal}$. Government Code, sec. 25373(d). The exemption is not self-executing; in order to claim it, a religious corporation must object to the application of the landmarking law to its property, and "determine in a public forum that it will suffer substantial hardship [defined in the section] if the [landmarking designation] is approved." Id. at sec. 25373(d)(2). The "public forum" referenced in the section is simply a meeting open to the public, not a review of the exemption by a public body. For commentary on the California legislation, see Madeleine Randal, Comment, Holy War: In the Name of Religious Freedom, California Exempts Churches from Historic Preservation, 37 Santa Clara L. Rev. 213 (1996); Felipe M. Nunez \& Eric Sidman, California's Statutory Exemption for Religious Properties from Landmark Ordinances: A 
Development Corp. v. California ${ }^{56}$ the California Supreme Court upheld the statutory exemption against claims that it violated the California Constitution or the Establishment Clause of the federal constitution. The Court did not go so far as to claim that an exemption this broad was constitutionally required; instead, it recognized that the state legislature had discretion to conclude that religious corporations would be significantly burdened by the landmarking of any of their noncommercial property, and therefore to accommodate them in this way. ${ }^{57}$

The second model of exemption for religious structures from landmarking regimes is exemplified by the decision of the Washington Supreme Court in First Covenant Church v. Seattle. ${ }^{58}$ The Court in an earlier decision had ruled that the federal Free Exercise Clause required all houses of worship to be exempt from such laws. ${ }^{59}$ After the U.S. Supreme Court vacated and remanded the decision in light of Employment Division v. Smith, ${ }^{60}$ the Washington Supreme Court reaffirmed its original result, resting its conclusions both on the "hybrid rights" theory discussed in Smith ${ }^{61}$ and on the state constitution. Thus, under First Covenant, "houses of worship" are entirely exempt from landmark designation, though other property owned by

Constitutional and Policy Analysis, 12 J. L. \& Religion 271 (1995-96).

${ }^{56} 13$ P.3d 1122 (Ca. 2000), cert. denied, 121 S. Ct. 1735 (2001).

${ }^{57}$ We discuss the California exemption, and its validation in East Bay, extensively in Lupu \& Tuttle, Distinctive Place, note 7 supra, passim. We conclude that the exemption is not required by any sensible rendering of Separationist principle, and that it is far too great a departure from Neutralism to be sustained. Id. at 74-76.

\footnotetext{
${ }^{58} 840$ P.2d 774 (Wash. 1992).

${ }^{59}$ First Covenant Church v. Seattle, 787 P.2d 1352 (1990).

${ }^{60} 499$ U.S. 901 (1991).

${ }^{61} 494$ U.S. at xxx.
} 
religious institutions, even if put to religious uses, presumably is not. ${ }^{62}$

A third possible model of exemption is suggested by the decision of the Massachusetts Supreme Judicial Court in Society of Jesus v. Boston Landmarks Commission. ${ }^{63}$ The Commission had designated as a landmark elements of the interior of The Church of the Immaculate Conception in South Boston. As the Court described it, "[t]he designation restricted permanent alteration of the "nave, chancel, vestibule and organ loft on the main floor - the volume, window glazing, architectural detail, finishes, painting, the organ, and organ case." ${ }^{964}$ Relying exclusively on the state constitution, the Court distinguished an earlier ruling in which it had approved of landmark designation of the exteriors of churches to the extent they were "open to view from a public way." ${ }^{65}$ Landmarking of an interior space, the Court concluded, "is substantially more invasive, reaching into the church's actual worship space.",66

The final model is one of no exemption at all. This is exemplified by the decision of the U.S. Court of Appeals for the Second Circuit in Rector of St. Bartholomew's Church v. City of New York. ${ }^{67}$ The St. Bartholomew's decision involved an attempt by church officials to escape a landmark designation in order to demolish what the court described as an "auxiliary structure

${ }^{62}$ It is unclear whether the exemption is limited to properties used exclusively or primarily for worship purposes, or whether it might extend to residential properties used occasionally for worship. The rationale of First Covenant, which rests heavily on the values of religious expression associated with design of houses of worship, would suggest that places used only occasionally for worship would not qualify.

${ }^{63} 409$ Mass. 38, 564 N.E.2d 571 (1990).

${ }^{64} 564$ N.E. $2 d$ at 572.

${ }^{65}$ Id. at 573 (citing Opinion of the Justices, 333 Mass. 783, 784 (1955)).

${ }^{66}$ Id. at 573.

${ }^{67} 914$ F.2d 348 (2d Cir. 1990). 
next to the Church's main house of worship." ${ }^{98}$ The church wanted to tear down this building, which housed a variety of church activities including some of a decidedly religious character, and replace it with a high-rise office tower that would include both church uses and incomeproducing office space. In denying the church the right to escape the landmark designation on free exercise grounds, the Court of Appeals relied heavily on the then quite recent decision in Smith. The Landmarks Law in New York City, the court concluded, is a religion-neutral law of general applicability, and the Free Exercise Clause does not support claims of exemption from such regulatory regimes. ${ }^{69}$

All four models of exemption present different issues for those who wrestle with questions of the permissibility of preservation grants. The California model appears to exclude all regulation of religious property, but the scheme involves self-designation. Presumably, a religious corporation could assent to landmarking, and then seek a preservation grant. ${ }^{70}$ The First Covenant model excludes all houses of worship from landmarking designation, but here too it is not clear if religious entities may, as in California, consent to the designation and seek a grant to aid in preservation. The rule in the Society of Jesus decision is limited to church interiors, and expressly reaffirms the possibility of designation of the exteriors of houses of

\footnotetext{
${ }^{68}$ Id. at 350 .
}

${ }^{69}$ Id. at 354. The Court also relied on the fact that the major burden on the Church was financial, rather an interference with its religious practice. Id. at 354-55. It therefore left open the possibility that a landmarking of worship premises that did so interfere might produce a different result, but it did not explain how or why, in light of Smith, such facts would produce a different result. Smith itself involved a worship practice, the use of peyote by Native American Church members, and nothing in the Smith opinion suggests that the character of the regulated practice will have any bearing upon application of the rule that the Smith Court announced.

${ }^{70}$ Such a grant would be barred by the state constitution in California, see Frohliger v Richardson, 63 Cal. App. 209, 218 P 497 (Cal. Ct. App. $1^{\text {st }}$ Dist. 1923), although other states with less absolute barriers to such grants might adopt the California model of deregulation of property owned by religious entities. 
worship. Once again, however, the exemption for interiors seems permissive, not mandatory; houses of worship are not obliged to claim it. ${ }^{71}$ And the analysis in St. Bartholomew's Church suggests no room for exemptions at all; from the decision's general character, and its reliance on Smith, one might fairly presume that houses of worship, interiors as well as exteriors, are (as a matter of federal law) fair game for landmark designation in the Second Circuit. In such a jurisdiction, the question of whether preservation grants are permissible in any case, involving buildings devoted to worship, seems particularly pressing.

B. The Problem of Historic Preservation Grants

\section{The Dueling Opinion Letters}

Whatever the outcome on the regulatory side, has the movement toward Neutralism moved far enough to encompass state grants to religious groups for the preservation and upkeep of historic structures in which religious worship still occurs? That is, in those states which recognize no exemption from landmarking for structures devoted to worship, or an interior exemption only, may the preservation of such structures be supported financially by the state?

In the late 1980's, John Shannahan, the Director of the Connecticut Historical Commission, was in a quandary over this precise question. The Commission had authority to make grants for the purpose of preserving historic buildings in Connecticut, and many of the buildings of historic character in the state were churches. Various towns and cities in Connecticut had landmarked their historic churches, and a number of these churches had applied

${ }^{71}$ Our own view, expressed in Distinctive Places, note 7 supra, at 88-90, is that First Covenant goes too far, and Society of Jesus gets the matter right. Houses of worship should have the same rights as other nonprofit associations (but no more) to complain, on the religion-neutral ground of compelled speech, about exterior designations. Interior designations, on the other hand, may press into worship space so deeply that we think they are beyond the state's jurisdiction altogether, so that landmark designations of interiors should not be permitted with or without the church's consent. 
to the state historical commission for preservation grants. The Director was quite unsure, however, whether the Religion Clauses of the state or federal constitution would permit a grant to religious groups which controlled such buildings, or (regardless of who controlled the building) a grant to preserve a structure with religious use and/or significance. The Director decided to ask for a legal opinion from the chief lawyer of the Executive Branch of the State of Connecticut Joseph I. Lieberman, then Attorney General of the State.

In a letter dated July 5, 1988, Attorney General Lieberman provided his opinion. ${ }^{72}$ After surveying what he deemed the relevant Connecticut and federal precedents on the subject, including a pair of relatively recent memoranda by federal agency lawyers who asserted that historic preservation grants to religious institutions were constitutionally questionable, ${ }^{73}$ Lieberman concluded that such grants were indeed permissible in a variety of circumstances. In his view, these grants served legitimate purposes in the preservation of historical structures in the state, they advanced religion only incidentally, they would not entangle the granting agency in religious affairs, and they would not be perceived as state endorsement of religion. Attorney General Lieberman distinguished the Nyquist decision in three ways. First, he noted that the "maintenance and repair" grants in Nyquist left a substantial amount of discretion in the private institutions to decide how to allocate the funds; historic preservation grants are much more

${ }^{72}$ Letter from Attorney General Joseph I. Lieberman, to John Shannahan, Director, Connecticut Historical Commission, July 5, 1988 (hereafter "Lieberman Letter") (copy on file with the authors and the Boston College Law Review).

${ }^{73}$ Id. at 4, n. 1 (citing a memorandum written in 1982 from Ralph W. Tarr, Deputy Assistant Attorney General, Office of Legal Counsel, Department of Justice, to William H. Coldiron, Solicitor of the Interior, U.S. Department of the Interior, and another written in 1979 by James D. Webb, Associate Solicitor, Conservation and Wildlife, U.S. Department of the Interior). 
precisely targeted. ${ }^{74}$ Second, the grants in Nyquist went to a group of institutions dominated numerically by Roman Catholic schools; the Connecticut grants went to a far wider and more religiously pluralistic group of sects. ${ }^{75}$ Third, the grants disapproved in Nyquist paid a substantial portion of the maintenance budget of sectarian schools; by contrast, the historic preservation grants tended to be significantly smaller, both in absolute terms and as a percentage of total preservation costs. ${ }^{76}$

Seven years later, in 1995, a federal agency renewed the question that Attorney General Lieberman had answered for Director Shannahan. The Solicitor of the United States Department of the Interior, John Leshy, had drafted an opinion on the subject of "Historic Preservation Grants for Religious Properties " for the Director of the National Park Service, Roger Kennedy. Leshy presented the draft opinion, which suggested that intervening changes in constitutional law might have removed the legal impediments to such grants, to Walter Dellinger, who was then the Assistant Attorney General in the Office of Legal Counsel in the Department of Justice. After surveying a number of the same precedents as the Lieberman letter had discussed, including in particular Nyquist and Tilton, and qualifying his conclusion with defensive assertions that the "question of government aid to religious institutions is ... difficult ...,"77 and "the Supreme

${ }^{74}$ Lieberman letter, note 72 supra, at 9.

${ }^{75} \mathrm{Id}$.

${ }^{76}$ Id. ("Not only was the Nyquist Court concerned that the subject aid would be massive in absolute terms, but also that it might have a 'massive' proportionate effect on such schools, making it possible for them to obtain their 'entire maintenance and repair budgets' from state tax-raised funds.”) (citing Nyquist, 413 U.S. at 774).

${ }^{77}$ Memorandum for John Leshy, Solicitor, United States Department of Interior, from Walter Dellinger, Assistant Attorney General, Office of Legal Counsel, U.S. Department of Justice, Re: Historic Preservation Grants to Religious Properties, dated October 31, 1995, at 7 (hereafter cited as "Dellinger Memorandum") (copy on file with the authors and the Boston College Law Review) (http://www.usdoj.gov/olc/doi.24.htm). 
Court's jurisprudence in this area is still developing, ${ }^{, 78}$ Dellinger's memorandum expresses the ultimate judgment "that a court applying current precedent is most likely to conclude that the direct award of historic preservation grants to churches and other pervasively sectarian institutions violates the Establishment Clause." ${ }^{79}$ The Dellinger memorandum remains the policy of the federal government with respect to expenditures for the upkeep of buildings devoted to worship. ${ }^{80}$

Did then-Attorney General Lieberman have the better view in 1988 than then-Assistant Attorney General Dellinger in 1995? The Lieberman Letter tilts heavily toward Neutralism, which had displaced Separationism to some extent by 1988, and to an even greater extent by 1995, when Dellinger wrote. Moreover, decisions rendered since 1995 have to a considerable extent reduced the force of Separationism still further, especially in cases involving government financial support that benefits religious institutions along with a broad mix of secular entities. If Lieberman was right in 1988, his view must be even more correct today. And yet, as noted in Part II above, the shift to Neutrality and away from Separationism is incomplete. Can one fairly say, as Lieberman did in 1988, that historic preservation grants are so different from the "maintenance and repair" grants struck down in Nyquist that the shift toward Neutrality is sufficient to validate grants targeted at historic preservation of structures currently devoted to

${ }^{78}$ Id. at 8.

${ }^{79}$ Id. The Dellinger memorandum also considered briefly the question whether the Free Exercise Clause limited the government in landmarking religious buildings in the first place. Although pretending not to take a position on the issue, the letter betrayed its author's Separationist leanings - also suggested by its conclusion on the question of grants - by asserting that the reasoning of the most prominent decision exempting religious houses of worship from landmarking laws "is persuasive." Id. at 5-6 (citing First Covenant, and distinguishing St. Bartholomew's Church v. City of New York, 914 F.2d 348 (2d Cir. 1990), cert. denied, 499 U.S. 905 (1991)).

${ }^{80}$ See text at notes $82-93$, infra. 
worship? Indeed, if Lieberman is correct about preservation grants, involving houses of worship, one would think that Nyquist, involving sectarian school buildings, should be overruled.

This is obviously an unfinished story. For its latest chapters, we turn to policies articulated, and practices engaged in, concerning historic preservation grants by those on the front line of administration. As the tale unfolds, its lessons suggest significant - and perhaps appropriate - hesitation about the shift from Separationism to Neutralism.

2. Current Policy and Practice

Support for historic preservation is available from the federal government and many states, and takes a variety of forms.$^{81}$ Beyond the official recognition that comes with listing a property in the National Register of Historic Places or a state's register, owners of historic properties may also receive technical assistance, tax incentives, low-interest loans, and grants to assist them in restoring and preserving the structure. In examining the constitutional implications of providing such assistance to religious institutions, we will focus on public grants. We look first at the federal programs that provide such grants, and then turn to state programs.

\section{A. Federal Historic Preservation Grants}

The National Historic Preservation Act (NHPA), enacted in 1966, provides the criteria for determining which properties are eligible to be listed in the National Register, and also empowers the Department of the Interior to make grants - either directly or through a state historic preservation office - to subsidize preservation and restoration of listed properties. ${ }^{82}$ The

${ }^{81}$ There are a range of nongovernmental funding sources for preservation of houses of worship. For more information on such sources, see the website of Partners for Sacred Places,

${ }^{82}$ The National Historic Preservation Act, 16 U.S.C. $\S 470$. Implementing regulations for the Act can be found at 36 CFR parts 60-63, 65-68. Further information about federal programs for historic preservation can be found on the website of the National Park Service, http://www.cr.nps.gov. See also Cohen, supra note 5 (describing federal historic preservation programs). 
regulations permit "properties owned by religious institutions or used for religious purposes" to be listed in the National Register only if the properties "deriv[e] primary significance from architectural or artistic distinction or historical importance, ${ }^{93}$ and not because of the structures' religious significance. At present, several thousand properties owned by religious institutions and actively used for religious purposes are listed on the National Register. ${ }^{84}$

At least since the early 1980s, the federal government has followed a Separationist policy regarding historic preservation grants to religious institutions. ${ }^{85}$ Concerns about violating the Establishment Clause led the federal government to deem such properties ineligible for any program that provides grants for "bricks and mortar." Reacting against this policy, Congress amended the NHPA in 1992 to authorize preservation grants to religious properties:

[G]rants may be made under this subsection for the preservation, stabilization, restoration, or rehabilitation of religious properties listed in the National Register of Historic Places, provided that the purpose of the grant is secular, does not promote religion, and seeks to protect those qualities that are historically significant. ${ }^{86}$

Congress's directive, however, did not change the policy of the Justice Department or the practice of the federal agencies; both policy and practice remained fundamentally Separationist. Citing the Dellinger memorandum, the National Parks Service's Historic Preservation Funds Grants Manual bars grants for "construction repair costs, or real property acquisition costs"

${ }^{83} 36$ CFR $§ 60.4$ (a).

${ }^{84}$ E-mail from Patrick Andrus, Historian, National Register of Historic Places, to Joann Corey, July 19, 2001 (copy on file with the authors and the Boston College Law Review).

${ }^{85}$ Letter to the Honorable James G. Watt, Secretary of the Interior, from Frederick N. Khedouri, Associate Director, Office of Management and Budget (Dec 14, 1981) (referenced in Dellinger Memorandum and in Lieberman letter).

${ }^{86} 16$ USC $\S 470(\mathrm{e})(4)$. 
related to historic properties owned by religious institutions. ${ }^{87}$ The "Save America's Treasures" program, administered jointly by the National Park Service and the National Trust for Historic Preservation, contains a similar prohibition on funding "Historic properties and collections associated with an active religious organization (for example, restoration of an historic church that is still actively used as a church). ${ }^{198}$

The Separationist policy reflected in the Dellinger memorandum extends to other federal programs that provide grants for "bricks and mortar." ${ }^{\text {"99 }}$ The Department of Housing and Urban Development's Community Development Block Grant (CDBG) Program authorizes the Department to make grants for preservation and reconstruction of structures serving a wide variety of purposes in a community, benefitting both commercial and non-profit institutions. ${ }^{90}$ The CDBG program, however, imposes strict restrictions on any funding used to rehabilitate

${ }^{87}$ Historic Preservation Funds Grants Manual, Chapter 6, E(4) (October 1997).

${ }^{88}$ Save America's Treasures, FY 2002 Historic Preservation Fund Grant Application Form, http://www2.cr.nps.gov/treasures/2002SATpackage.pdf (on file with the authors), at p.2. See also letter from Robert Stanton, Director, National Park Service to Senator Slade Gorton (Feb. 4, 2000) (explaining that because of the Justice Department's interpretation of the Establishment Clause, the Park Service cannot spend the \$151,000 earmarked in Public Law 106-113, under the Save America's Treasures program, for the historic preservation of St. Nicholas Greek Orthodox Cathedral in Tarpon Springs, Florida) (copy on file with the authors and the Boston College Law Review).

${ }^{89}$ In addition to programs discussed in this paragraph, Separationist policy is also visible in the following federal programs administered by the Department of Housing and Urban Development that provide grants for preservation, restoration, or construction: the Home Investment Partnerships Program, 24 CFR $\$ 92.257$ (barring religious organizations from participating in program that provides federal money to rehabilitate or construct low-income housing); Housing Opportunities for Persons with AIDS, 24 CFR $\S 574.300(c)$ (2) (restrictions on use of program funds for rehabilitation or conversion of structures owned by religious organizations); the Emergency Shelter Grants Program, 24 CFR $\S 576.23$ (b) (restrictions on grants to convert or rehabilitate structures owned by religious organizations); the Supportive Housing Program, 24 CFR $\S 583.150$ (restrictions on participation of religious institutions on program of housing and services for the homeless).

${ }^{90} 24$ CFR $\S 570.208$. 
structures owned by religious entities. In order to receive funding, the structure must be leased to a "wholly secular" entity -- for no more than the fair market value of the property before the funded rehabilitation -- and used only for secular purposes. ${ }^{91}$ Similarly, the Federal Emergency Management Agency (FEMA) provides Federal Disaster Assistance grants to a broad variety of "non-profit facilities" that provide basic services to the general public, including schools, museums, community centers, and libraries. ${ }^{92}$ The category of non-profit facilities eligible for FEMA disaster assistance grants specifically excludes facilities used for religious purposes. ${ }^{93}$ Despite this rather consistent Separationism, a closer look at federal programs that provide grants for "bricks and mortar" reveals a somewhat more complicated picture." Religious properties affected by disasters are eligible for low-interest loans through a program administered by the Small Business Administration; $;{ }^{95}$ and may receive FEMA Hazard Mitigation Grants as part of a community-wide mitigation project. ${ }^{96}$ Indeed, FEMA's website celebrates the financial support its Hazard Mitigation Grants program provided to relocate a church out of a

\footnotetext{
${ }^{91} 24$ CFR § 570.200 (j).
}

${ }^{92} 44$ CFR § 206.221(e) (definition of "non-profit facilities" eligible for public disaster assistance grants); 44 CFR $\S 206.222$ (providing that non-profit facilities, along with state and local governments and indian tribes, are eligible to receive public disaster assistance grants).

${ }^{93} 44$ CFR $\S 206.221$ (e)(1) (category of educational facility eligible for disaster assistance grant "does not include buildings, structures, and related items used primarily for religious purposes or instruction"); FEMA Response and Recovery Directorate Policy Number 9521.1 (www.fema.gov/r-n-r/pa/9521_1.htm) (defining "community center" in 44 CFR § 206.221(e)(6) to exclude "Facilities established or primarily used for religious -- or similar -- activities").

${ }^{94}$ See, for example, the recent announcement that HUD will permit the use of grant money for maintenance and repair of structures owned by religious institutions. See supra note 41.

\footnotetext{
${ }^{95}$ Physical Disaster Business Loans Program, 13 CFR §123.200.

${ }^{96}$ For the Flood Mitigation Assistance Program, see 44 CFR §78.12.
} 
flood plain. ${ }^{97}$ In addition, the Church Arson Prevention Act of 1996 provides low-income reconstruction loans to any non-profit organization, including religious institutions, victimized by arson or terrorism motivated by racial or religious animus. ${ }^{98}$ When several historic churches -and a number of other houses of worship -- were seriously damaged because of the bombing of the Murrah Federal Building in Oklahoma City, FEMA and the Department of Housing \& Urban Development initially refused to provide federal aid for their reconstruction. ${ }^{99}$ The agencies later relented when Congress specifically directed that "notwithstanding any other provision of law, such funds may be used for the repair and reconstruction of religious institution facilities damaged by the explosion in the same manner as private nonprofit facilities providing public services. ${ }^{, 100}$ Ultimately, Oklahoma City churches received over $\$ 6$ million in federal funds to

\footnotetext{
97“"A Church Gets Moved Out of Harm's Way in Pennsylvania," (www.fema.gov/nwz00/nwz00_22.htm).

${ }^{98}$ The Church Arson Prevention Act of 1996, Pub. L. No. 104-155, 110 Stat. 1392 (1996)
} (Section 4 creates the Loan Guarantee Recovery Fund). See also the Department of Housing and Urban Development regulations governing the loan fund established by the Church Arson Prevention Act, 24 CFR § 573. Professor Esbeck collects these and other examples of the trend away from Separationism in Carl Esbeck, Myths, Miscues, and Misconceptions: No-Aid Separationism and the Establishment Clause, 13 Notre Dame J. L., Ethics, \& Pub. Pol'y 285, 285-6 \& n.4 (1999)

${ }^{99}$ See Eugene Volokh, Equal Treatment is Not Establishment, 13 Notre Dame J. of L., Ethics, \& Pub. Pol. 341, 354, n.22 (1999).
${ }^{100} 104$ PL 19 (141 Cong. Rec. H 6607, *6636). See also statements of Rep. Istook: Mr. Speaker, Congress is aware that several downtown churches were severely damaged as a result of the April 19, 1995, terrorist bombing of the Alfred P. Murrah Federal Building in Oklahoma City. Among these are First United Methodist Church, First Baptist Church, St. Paul's Episcopal Cathedral and St. Joseph's Catholic Church. These churches assisted in the emergency relief effort immediately after the bombing and one was even used as a temporary morgue for victims of the blast.
These religious institutions have been informed by the Federal Emergency Management Agency that under current regulations they are not eligible for any federal disaster assistance for the repair and reconstruction of their facilities. However, Congress recognizes that the Oklahoma City bombing is a unique case. 
help repair damage from the bombing. ${ }^{101}$

Federal historic preservation programs also depart from the robust Separationism articulated in the Dellinger memorandum. Although Department of the Interior policies prohibit the use of federal funds for "development" -- i.e., preservation and renovation -- projects involving historic religious properties, the policies allow grants to such properties for "predevelopment" costs. ${ }^{102}$ "Pre-development" costs include architectural plans for restoration or renovation of the structure, consulting fees incurred in preparing forms for inclusion in the National Register of Historic Places, and other similar expenses.

The restoration of Ebenezer Baptist Church, financed by a grant through the "Save America's Treasures” program as part of the Martin Luther King, Jr. National Historic Site, provides an illuminating study in the limits of Separationism as an official policy. Martin Luther King, Jr. was a co-pastor of Ebenezer Baptist Church during the years of his leadership of the civil rights movement, and he preached many of his famous sermons on civil rights, race relations, and civil disobedience from its pulpit. The congregation of Ebenezer Baptist still owns the church property, but leased the historic church to the National Park Service as part of a deal that provided the congregation with a parcel adjacent to the historic church, on which the

The bombing was a single, man-made assault directed against our national government. These churches, like the other businesses and residences in the damaged area, were innocent bystanders to a violent attack on the federal government. This special instance is therefore distinguished from other kinds of disasters in which religious buildings may be damaged. Congress thus agrees that religious institutions in Oklahoma City should be eligible for the federal assistance provided in this bill in the same manner as nonprofit organizations providing public services.

141 Cong. Rec. E 1439 (June 29, 1995).

${ }^{101}$ Pat Gilliland, Church Thanks City Council[:] Funds Assist in Restoration, The Daily Oklahoman, April 2, 1997, III/1.

${ }^{102}$ Historic Preservation Fund Grants Manual, Ch. 6 (E)(3) (October 1997). 
congregation has built a new sanctuary. ${ }^{103}$ Under the terms of its 99 -year lease to operate the church as a historic site, the Park Service conducts tours and offers programs open to the public. The congregation of Ebenezer holds its regular services in the new sanctuary but remains free to use the historic church for special worship events, at which times the Park Service closes the church to the general public. ${ }^{104}$ Accurate presentation of Dr. King's life, not to mention the entire Civil Rights Movement, requires attention to the important role of African-American churches, but a consistent Separationist policy would preclude the close relationship between the Park Service and Ebenezer Baptist Church. ${ }^{105}$

\section{B. State Historic Preservation Grants}

To the extent that State Historic Preservation Offices act merely as conduits of federal funds, their grants are bound by the Separationist policies reflected in the Dellinger memorandum. A significant number of states, however, provide additional funds for historic preservation, and these state programs reflect quite disparate attitudes toward financing religious

${ }^{103}$ For descriptions of the agreement between Ebenezer Baptist Church and the National Park Service, see Kevin Sack, "A New Place to Nourish One Dreamer's Legacy," N.Y. Times, Mar. 8, 1999, at A12, col. 1; Gayle White, "Historic Old Church to Get New Sanctuary," Atlanta J. \& Const., Mar. 23, 1997, at 5C; "Park Service Takes Over Legacy of Historic Ebenezer Baptist," Atlanta J. \& Const., May 1, 1996, at 1B.

${ }^{104}$ See E.N. Smith, "Park Service Will Preserve Historic King Church; Congregation Moves to Make Room for Progress," Chattanooga Times/Chattanooga Free Press, Feb. 20, 1999, at F1 ("A 99-year lease will enable the Park Service to offer tours, lectures, book signings and other programs, including live choral performances at the historic church. However, members of the congregation will still be allowed to celebrate special occasions there").

${ }^{105}$ For commentary on the Park Service's struggles in managing sacred sites, especially those of American Indians, see Charles Levendosky, "Respecting Sacred Sites: Why not Accommodate Indians at Devils Tower as we Accommodate Christians Elsewhere?" Denver Rocky Mountain News, May 18, 1997, at 1B; Shawna Lee, Note: Government Managed Shrines: Protection of Native American Sacred Site Worship, 35 Val. U.L. Rev. 265 (2000). See also id. at 306-07 (discussing the Park Service's agreement with Ebenezer Baptist Church). 
properties. ${ }^{106}$ We look first at programs that follow the federal government's Separationism, and then at programs that adopt the Neutralism represented by the Lieberman letter.

\section{Separationist Policies}

Of the state historic preservation programs that share the federal government's Separationist policy, which bars most preservation grants to religious properties, some appear to do so because they find the Dellinger memorandum either persuasive or binding. ${ }^{107}$ Other states adopt a Separationist policy on particular state law grounds. In California, state historic preservation grants to religious organizations appear to be barred by the 1923 decision of the state's Court of Appeals in Frohliger $v$ Richardson, which held that a state appropriation for restoration of the San Diego Mission was barred by the state constitution's absolute ban on funding sectarian institutions. ${ }^{108}$ In Georgia, the state's Division for Natural Resources recently

\footnotetext{
${ }^{106}$ For a survey of state historic preservation grant programs, see state-by-state chart developed by the National Trust, at http://www.nationaltrust.org/help/State_Funding.pdf (on file with the authors).

${ }^{107}$ See, e.g., the responses of the Indiana, Montana, and Nevada state historic preservation offices (email from Jon Smith, Deputy Director, Indiana State Historic Preservation Office, to Joann Corey, July 20, 2001; from Herb Dawson, Deputy Director, Montana State Historic Preservation Office, to Joann Corey, July 23, 2001; from Alice Baldrica, Nevada State Historic Preservation Office, to Joann Corey, July 23, 2001) (all linking state limits on grants to religious institutions to federal policies) (copies of all emails to Joann Corey cited herein are on file with the authors and the Boston College Law Review). Minnesota declares religious properties ineligible to receive state historic preservation grants, but does not explain why. Minnesota State Historical Society, State Grants-in-Aid Program Project Guidelines 1 (1998) (website address: www.mnhs.org/about/grants/pdffiles/guidelines.pdf).

${ }^{108}$ Frohliger v. Richardson, 63 Cal. App. 209, 218 P. 497 (1923). The California Constitution provides that no government entity may "...grant anything to or in aid of any religious sect, church, creed, or sectarian purpose." 63 Cal. App. at 212 (citing California Constitution Article IV, Section 30) (the same provision is now located at Article XVI, Section 5). The current picture in California is more complicated than the state constitutional analysis in Frohliger would suggest. Some "public spaces" in religious properties seem to be eligible for state historic preservation grants, though the precise nature of the eligible projects is unclear from the grants guidelines, which indicate that the questions will be resolved by the administrator on a case-by-case basis. See California Office of Historic Preservation, Grant Application
} 
discontinued its practice of awarding historic preservation grants to religious organizations because of concerns that the practice violated the state constitution's (strongly Separationist) religion clause. ${ }^{109}$ Virginia also has strict constitutional limits on state grants to religious organizations, but allows churches to transfer ownership of the property to a secular non-profit institution -- which would be eligible for state historic preservation grants, and would operate the church as a historic site open to the public -- and the congregation can then lease the worship space back from the secular entity. ${ }^{110}$

\section{Neutralist Policies}

Many, and perhaps most, of the states that offer their own historic preservation grants do not share the federal government's Separationist policies, ${ }^{111}$ though these states impose a wide

and Procedural Guide for the California Heritage Fund Grant Program 1, 12 (2001) (http://ohp.parks.ca.gov/pages/1054/files/nov 01chfgrantapp.pdf).

109“'State suspends historic site grants to churches," Atlanta Journal and Constitution (May 25, 2000) 5C. See also email from Cherie Blizzard, Grants Coordinator, Historic Preservation Division, Georgia Department of Natural Resources, to Joann Corey, July 16, 2001 (citing state constitution as the reason the state no "no longer makes historic preservation grant[s] to religious organizations") (copy of the e-mail on file with the authors and the Boston College Law Review). Georgia's state constitution provides that: "No money shall ever be taken from the public treasury, directly or indirectly, in aid of any church, sect, cult, or religious denomination or of any sectarian institution.” Georgia Const. Art. 1, Sect. 2, Par. 7 (1983).

${ }^{110}$ See email from Kathleen Kilpatrick, Virginia State Historic Preservation Office, to Joann Corey, July 23, 2001 (describing grant to Christ Church in Lancaster, Va.) (copy on file with the authors and the Boston College Law Review). The prohibition on funding properties owned by religious organizations is found in Va. Code $\S 10.1-2213(\mathrm{~A})(3)$. New York City's Landmarks Preservation Council's Historic Preservation Grant Program is funded by a federal Community Development Block Grant; to comply with the CDBG restrictions on funding religious properties, the Council will only fund religious properties where ownership has been transferred to a secular non-profit entity which then manages the property, and can lease back a portion to the religious entity for use as worship space. See email from William Neely, Director, Historic Preservation Grant Program, New York City Landmarks Preservation Commission, to Joann Corey, July 17, 2001 (copy on file with the authors and the Boston College Law Review).

${ }^{111}$ Because the Establishment Clause binds the states as well as the federal government, the Dellinger memorandum's interpretation, if correct, should apply to both federal and state funding streams. That many states deviate from the memorandum reflects 1) the phenomenon of 
range of conditions on grants to religious organizations. One feature shared by all programs that finance historic preservation of religious properties -- and indeed by the federal requirements for listing religious properties in the National Register of Historic Places -- is that the property's significance is determined on secular terms, such as its architectural merit or role in important historical events. $^{112}$

A common condition limits grants to religious institutions to repairs that are publicly visible. Texas and New Jersey, for example, only support work on the exterior of religious properties. $^{113}$ Other jurisdictions, however, permit grants for restoring and preserving the interior of religious properties, provided that the properties offer the public a reasonable opportunity to

independent voices in constitutional interpretation within the federal system, and 2) substantial uncertainty about the content and path of Establishment Clause principles.

${ }^{112}$ See, e.g., Lieberman Letter, note 72 supra, at 15 ("Any religious property which is the subject of a state preservation grant should meet standard criteria for grant-worthiness based on the property's intrinsic historical, architectural, or other cultural values"). See also National Historical Preservation Act (criteria for listing religious property).

${ }^{113}$ See Guidelines for Preservation Grant Applications, Texas Historical Commission 4 (website address for the form: www.thc.state.tx.us/forms/tptf/TPTFGuidelines02.pdf); Garden State Historic Preservation Trust Fund, 2002 Grant Guidelines 16 (website address for the form: www.njht.org/guidelines-2002.pdf) (New Jersey program does not fund "costs involving the interiors of buildings used primarily for religious worship or a religious purpose"). The Arizona Heritage Preservation Grant Fund (administered by the State Parks Commission) seems to allow grants to churches for exterior work, though its website indicates that churches are ineligible. See email from Jim Garrison, Arizona State Historic Preservation Office, to Joann Corey, July 12, 2001 ("Active churches are eligible for grants so long as the grant is limited to the exterior or clearly architectural elements") (copy on file with the authors and the Boston College Law Review), see also www.pr.state.az.us/partnerships/grants/histpres.html. Florida has a similar limitation: "Grant assistance to projects which serve a religious purpose if restricted to exterior features or that work which can be viewed from the public right-of-way" (email from Robert C. Taylor, Historic Preservationist Supervisor, Florida Department of State, Division of Historical Resources, Bureau of Historic Preservation, to Joann Corey, July 16, 2001) (copy on file with the authors and the Boston College Law Review). See also Maryland Historical Trust Capital Grant Program, Fiscal Year 2003 Grant Guidelines 3 ("Structures used for religious purposes may be eligible for MHT grant assistance for exterior work only and will be reviewed by MHT on a case by case basis") (www.marylandhistoricaltrust.net/capguide.pdf). 
view the interior "without being required to participate in or witness any religious activities."114

The New York State historic preservation program requires grantees that use grants for interior restoration to open the property "to the general public at least 12 times a year at reasonably spaced intervals."115 Pennsylvania requires that the benefitted property "must be open and accessible to the public on a regular basis, not less than 100 days per year." "16 In requiring public accessibility to state-subsidized interior portions of historical structures, these agencies treat religious institutions no differently than other grantees.

Somewhat more complicated are restrictions designed to segregate expenditures with primarily historical, architectural, or cultural value from benefits that flow primarily to the religious use of the property. Several states restrict the use of grants for "liturgical items." "117

\footnotetext{
${ }^{114}$ Colorado State Historical Fund, Grant Program Guidelines 21 (online at website: http://www.coloradohistory-oahp.org/publications/pubs/1412GuidelinesTO.pdf) (hereinafter "Colorado Guidelines"). See also Lieberman Letter, note 72 supra, at 15 ("if related work is done in a [religious] building's interior, the public must be provided with reasonable opportunity to view the restored structures (as often as possible) during times when no religious service or instruction is being conducted in the immediate vicinity"). The Lieberman Letter reflects current Connecticut practice. See email from Paul Loether, Connecticut Historical Commission, to Joann Corey, July 13, 2001 (copy on file with the authors and the Boston College Law Review); see also Connecticut Historical Commission, Historic Preservation Fund - Phase II Guidelines, www.chc.state.ct.us/HRF-Phase2.htm); New York State Office of Parks, Recreation and Historic Preservation, 9 NYCRR $\S$ 432.4(b) (reasonable accessibility requirement for any historic preservation grant made to not-for-profit entity); State of Vermont Historic Preservation Grants Program, email from Eric Gilbertson, Director, Vermont Division for Historic Preservation, to Joann Corey, July 24, 2001 ("We do not fund strictly religious items or interior work on areas not open to the public") (copy on file with the authors and the Boston College Law Review).

${ }^{115}$ Cohen, ALI-ABA study, supra note 5, at 7.

${ }^{116}$ Keystone Historic Preservation Grant Program (www.artsnet.org/phmc/key_guide.html).

${ }^{117}$ See generally Washington State Office of Archaeology and Historic Preservation, Rehabilitation Grant-in-Aid Program (email from Greg Griffith, Deputy State Historic Preservation Officer, Washington State Office of Archaeology and Historic Preservation, to Joann Corey, DATE) (“Clearly, we would not and could not fund rehabilitation of elements of
} 
Architectural elements included in this category are "stained glass windows illustrating religious themes," 118 "steeple crosses," ${ }^{, 119}$ and altars. ${ }^{120}$ Other states highlight their funding of such items, however, as central to preserving and restoring the fabric of historically significant features of the property. ${ }^{121}$ Vermont Historic Preservation grants are regularly awarded for preservation of church steeples. ${ }^{122}$ Texas attempts to draw the line between appropriate and inappropriate purposes by funding only "the difference between a rehabilitation project and a restoration project"; the religious organization must pay the rehabilitation costs - that which is necessary to make the space useable -- and the Texas Trust Preservation Fund will assist in expenditures beyond that point aimed at preserving or restoring the historic fabric of the property. ${ }^{123}$

the church that pertained to the liturgy or aspects that support the service or mission of the church") (copy on file with the authors and the Boston College Law Review); Colorado Guidelines, supra note 114, at 21-22 ("Grant funds cannot be used to restore religious symbols"); Lieberman Letter, note 72 supra, at 15 (concerns about funding "repair of a ritual object"); Illinois Historic Preservation Agency Grant-in-Aid Program (email from Theodore Hild, Deputy, Illinois State Historic Preservation Office, to Joann Corey, July 24, 2001) ("the grant project must be for non-liturgical purposes") (copy on file with the authors and the Boston College Law Review).

${ }^{118}$ Colorado Guide, supra note 114, at 22; email from Theodore Hild, supra note 117 (Illinois program).

${ }^{119}$ Colorado Guide, supra note 114, at 22.

${ }^{120}$ See email from Theodore Hild, supra note 117 (Illinois program ).

${ }^{121}$ Massachusetts and Vermont have both funded the preservation of stained-glass windows. For Massachusetts, see email from Elsa Fitzgerald, Assistant Director, Massachusetts Historical Commission, to Joann Corey, August 2, 2001 (copy on file with the authors and the Boston College Law Review). For Vermont, see email from Eric Gilbertson, supra note 114.

${ }^{122} \mathrm{Id}$.

${ }^{123}$ Terry Colley of the Texas Historical Commission explains: "for example, if a church wanted to replace an original slate roof with a shingle roof, we would make a grant to help them [use] slate" (email from Terry Colley, Deputy Director, Texas Historical Commission, to Joann Corey, July 24, 2001)(copy on file with the authors and the Boston College Law Review). 
Connecticut, following the Lieberman Letter, restricts any state preservation grants "without which certain religious activities could not continue," such as "extensive structural support work in a church, ${ }^{124}$ although other states fund work on the basic structure and foundations of religious properties. ${ }^{125}$

Finally, as a condition of receiving historic preservation grants, religious properties (like all other grantees) typically must convey to the granting agency an historic preservation easement. ${ }^{126}$ The easement binds the grantee and the grantee's successors to both affirmative and negative covenants, for a duration that may vary according to the value of the grant. A small grant may require only an easement for a term of 10 years, while a substantial grant may require an easement in perpetuity. ${ }^{127}$ The basic affirmative obligation is a promise to maintain the benefitted property -- the whole property, typically, and not just the portion affected by the grant

${ }^{124}$ Lieberman Letter, note 72 supra, at 15.

${ }^{125}$ See, e.g., email from Greg Griffith, Washington State HPO, to Joann Corey, supra note ("If a grant were to be awarded to a religious property, we would clearly restrict the use of the funds to the preservation of character defining features of the building or a project that would assure preservation of the building for safety, structural, functional reasons (i.e., foundation, roofing, ADA compliance, etc.)").

${ }^{126}$ See generally the National Park Service, Heritage Preservation Services, "Historic Preservation Easements," http://www2.cr.nps.gov/tps/tax/easement.htm (describing preservation easments); Arkansas Historic Preservation Program, Historic Preservation and Restoration Grants Manual, http://www.arkansaspreservation.org/preservation/Grants_HPRG_Manual.pdf, at 9; Arkansas Historic Preservation Program, Conservation Easements, http://www.arkansaspreservation.org/preservation/easements.asp. The Illinois Heritage Grant program has a sample covenant form available on its website: state.il.us/hpa/ps/hgmanual13covenant.pdf.

${ }^{127}$ See, e.g., Colorado Guide, note 114 supra, at 25 (describing variable terms of duration for easements depending on the value of the grant received); Texas Guide, note 113 supra, at 6 (same). 
-- according to specific preservation standards. ${ }^{128}$ In addition, grantees usually must guarantee reasonable public access to the property. ${ }^{129}$ The chief negative covenant is the grantee's promise not to make any changes, including demolition, to the historic features of the structure without the express consent of the preservation agency. ${ }^{130}$ If the grantee breaches one of the covenants, the preservation agency is entitled to bring an action for whatever injunctive relief is appropriate to cure the breach, including orders to restore improper changes to the structure or to maintain aspects of the property that the grantee has neglected. ${ }^{131}$

\footnotetext{
${ }^{128}$ See, e.g., Maryland's Historic Preservation Grant Program, Capital Grant Guidelines, http://www.marylandhistoricaltrust.net/capguide.pdf, at 10; Illinois Heritage Grant Program Manual, FY 2002 Grant-in-Aid Program, http:// state.il.us/hpa/ps/hgmanual.htm (grant recipients covenant to maintain their property according to the Secretary of the Interior's Standards for Historic Preservation Projects).

${ }^{129} \mathrm{The}$ public access requirement is not unique to religious entities but is a general feature of public grants to non-governmental entities, and is typically included as an affirmative covenant in the preservation easement. The New Jersey program is a good example of this requirement:
}

Public access is required to all resources receiving capital funds. The Trust and the grantee will negotiate the days and hours that the property will be open, based on the type of work funded by the grant, if the property is not accessible to the public at the time of application.

- A grant for exterior work requires the applicant to open the grounds to the public, but does not compel the applicant to make the interior accessible to the public.

- Interior work will require the applicant to open the building to the public.

- No additional access is necessary for properties open to the public on a regular basis, such as museums, libraries, or schools.

New Jersey Guide, supra note 113, at 19.

${ }^{130}$ See Illinois Heritage Grants Covenant form, supra note 126; New Jersey Guide, supra note 113 , at 19. The power to enforce the easement is generally given to the preservation agency that made the grant, but some grantors also permit the easement's benefit to be given to a different (usually local) historic society. See, e.g., Colorado Guide, supra note 114, at 25 (permitting preservation grant recipients to give easement to other approved preservation societies).

${ }^{131}$ See Illinois Grants Covenant form, supra note 126 (citing specific remedies available to the preservation agency). 
IV. Preservation Grants, Constitutional Symmetry, and the New Separationism

The story of historic preservation grants to religious institutions can be told in at least two ways. The first is a tale of Religion Clause jurisprudence as an inexorable march from Separationism to Neutralism. In this account, the Dellinger Memorandum, and the federal policies that rely on it, are anachronisms, the last vestiges of an era in which religious institutions were systematically excluded from a variety of public benefits. The ultimate destination of this march lies beyond the Lieberman Letter, which gives only qualified permission to the state historical commission to make grants to preserve religious properties. ${ }^{132}$ Neutralism, taken to its conclusion, ends up eliminating all distinctions between religious and secular institutions.

In tension with the story of Neutralism's relentless leveling of the distinction between religious and secular institutions is another account of contemporary Religion Clause jurisprudence. This story, with which we are in sympathy, is one of redrawing rather than obliterating the idea of Separationism. Though earlier Separationists overstated the distinctiveness of religious institutions, the Neutralists ignore the constitutionally salient reasons for maintaining limits on government with respect to such institutions. ${ }^{133}$ In this revised and more limited Separationism, defining the boundary between sacred and secular remains the essential task of Religion Clause theory. The distinctions reflected in contemporary state policies about preservation grants -- exterior vs. interior, liturgical items vs. others, structural support vs. historic fabric -- represent intuitive efforts to discern, in ways more nuanced than the absolute Separationism reflected in the Dellinger Memorandum, this line between sacred and

\footnotetext{
${ }^{132}$ Lieberman Letter, note 72 supra, at 15 (requiring disclaimers of government endorsement, and suggesting limits to state financing of structural support).

${ }^{133}$ We develop this idea in Lupu \& Tuttle, Distinctive Place, note 7 supra, at 78-92.
} 
secular.

At the heart of this more limited Separationism is the principle of Religion Clause symmetry. The requirement of symmetry is not an aesthetic one; rather, it reflects a larger, substantive theory of the Religion Clauses, pursuant to which the realm of worship of, and faith in, the transcendent lies beyond the jurisdiction of the state. ${ }^{134}$ This jurisdictional limit remains the same regardless of whether the legal context is one of regulatory burdens or state-conferred benefits.

If Religion Clause symmetry is a guiding principle, one helpful way to approach the problem of linedrawing in the provision of government funds to religious institutions is to analyze the question of permissible government regulation of such institutions. Like grantmaking officials, courts and legislatures that have considered the application of landmarking regimes to religious entities have wrestled with a problem of linedrawing. They have been pressed to decide whether exemption should extend to all noncommercial property owned by such entities, or just houses of worship, or, more restrictive still, only the interiors of worship structures. ${ }^{135}$ Our own view, advanced in earlier work, is that a Neutralist approach -- including a robust, religion-neutral doctrine of compelled speech -- provides appropriate protection for the exterior of religious properties. ${ }^{136}$ The exteriors of houses or worship, like the exteriors of other buildings, often form vital parts of the shared landscape, the cultural environment of the community in which the structures are located.

Regulation of the exterior of houses of worship, subject only to a religion-neutral doctrine

${ }^{134}$ See discussion in text at notes 43-45.

${ }^{135}$ For discussion of the current exemption models used by legislatures and courts, see text at notes 46-71, supra.

${ }^{136}$ Lupu \& Tuttle, Distinctive Place, supra note 7, at 74-76 and 88-90. 
permitting escape from being compelled to advance a message to which the organization no longer adheres, will allow for the landmarking of religious features of exterior design. Steeples, religious gargoyles and statuary on the outside of a worship structure, and other exterior symbols associated with a faith tradition all fall within the scope of appropriate historic preservation orders, because all are visible to passersby and constitute part of the historically significant design features of the property or neighborhood.

With respect to the interior of houses of worship, however, we believe that Separationist concerns about proper limits on the government's power with respect to religion require distinctive protections. Although the government's aesthetic and historic reasons for regulating interiors are no different from the justification for regulating exteriors, state intrusion on the interior of worship structures presents an unusually high risk that state agents will become coauthors of the religious experiences of those who worship in those spaces. Even if state agents make efforts to be sensitive to those concerns, a negotiation between state officials and church leaders over the location of an altar, or other liturgically significant features of interior design, would be an impermissible entanglement if ever one is to be found. ${ }^{137}$

This analysis of the scope of regulatory power over religious institutions suggests a resolution to the dilemma of historic preservation grants to such entities. Because the state has

${ }^{137}$ Although our analysis does not depend on the history of religious and legal attitudes about the interior of worship spaces, that history suggests that these spaces have for thousands of years been thought to possess a special character. Many viewed the interior of temples and churches as sacred and holy ground, and excluded the unclean from these spaces. Moreover, the concept of sanctuary, though never respected in American law, recognized the interior of religious structures as embassy-like, territory foreign to the nation-state in which the structures were located. State agents, pursuing state purposes, could be excluded from them, and fugitives from civil justice therefore could find refuge within them. Jorge L. Carro, Sanctuary: The Resurgence of an Age-old Right or a Dangerous Misinterpretation of an Abandoned Ancient Privilege?, 54 U. Cin. L. Rev. 747, 749-767 (1986) (describing history of religious and legal conception of sanctuary). 
constitutionally sufficient reasons to regulate the exterior of houses of worship, the state should also be free to subsidize the preservation of these exteriors, including religious symbols that constitute a part of such exteriors. ${ }^{138}$ Both regulation and subsidy are justified by the public, secular purposes served by historic preservation of the exteriors of religious structures.

In contrast, the state should be forbidden to subsidize what it cannot regulate, because the subsidy will inevitably be accompanied by regulatory conditions. The interiors of religious spaces undoubtedly possess great architectural, historical, and cultural significance, but they are also the places in which the faith envelops believers in the imagery and experience of reverence. ${ }^{139}$ Even if the religious institution consents to government regulation of the interior space, as a condition of receiving a preservation grant, enforcement of such conditions involves the same constitutional defect as direct regulation. ${ }^{140}$ Although the government may solve that problem by providing grants for preservation of interiors without such conditions, unrestricted

${ }^{138}$ Under the doctrine of compelled speech, a religious institution may be able to raise a religion-neutral constitutional defense to some types of regulation of the exterior, but the institution should also be free to waive that defense, and accept state regulation. Whether the waiver can be questioned or withdrawn by successors in interest with respect to the property presents a nice question, but not a religion-specific one. In contrast, a religious institution cannot waive the Establishment Clause concerns implicated in regulation of the interior of houses of worship.

${ }^{139}$ When the state finances the preservation of interiors of houses of worship on the condition that the public be provided access to such spaces, there exists a possibility, however remote, that the state is impermissibly steering public viewers into a religious experience. Such steering presents Establishment Clause questions akin to those presented in much stronger form by government-financed vouchers for purchase of services in religion-infused settings. For discussion of the steering problem associated with vouchers, see Ira C. Lupu \& Robert W. Tuttle, Sites of Redemption: A Wide-Angle Look at Government Vouchers and Sectarian Service Providers, xx J. Law \& Politics xx, in Symposium, The End of Separatism (forthcoming, 2002).

${ }^{140}$ If the benefit of the preservation were held by a non-governmental entity, the question of enforcement of conditions involving the interior of worship spaces opens up difficult constitutional questions about state action, of the sort initially addressed in Shelley v Kraemer, 334 US 1 (1948). 
direct funding of religious entities raises different, and perhaps even greater, constitutional problems. State expenditures require a public, secular purpose; without conditions that guarantee that the money will be used for such a purpose, state transfers to religious institutions are forbidden. ${ }^{141}$

Although it might seem solid, the boundary between interior and exterior presents some challenging questions, best exemplified by the dilemma of stained-glass windows. Such windows may have great historical or artistic significance, and make a substantial contribution to the structure's external appearance. Such windows often present religious themes, however, and help to create the worship experience through the play of light and imagery. Following our earlier mode of analysis, we look first at the regulatory question. May the state require a religious entity to preserve and maintain stained-glass windows that convey religious themes and are visible from within the sanctuary? We think the answer must be no. State control over the religious imagery in a worship space involves the entanglement concerns that motivate our basic judgment about state regulation of the interiors of houses of worship. If the state may not regulate the windows because of the religious imagery visible from within the worship space, the state also may not pay for the preservation or maintenance of such windows.

With respect to stained-glass windows that do not involve religious themes, regulation designed to preserve such windows presents a closer constitutional question. On the one hand, the use of color in such windows, and the ways in which they regulate the flow of light into the worship space, may shape religious experience. This argument, however, may prove too much for our taste; by analogy, at least some exterior features, such as building height, may also

${ }^{141}$ Even the most avid supporters of neutralism in Mitchell v. Helms, 530 U.S. 793 (2000) (plurality opinion), adhere to this proposition. Id. at 8xx. 
influence the experience of worshipers within. In our view, where the windows do not portray religious themes, or are not visible from within the worship space, the case for state financing becomes considerably stronger.

Even if our intuitions about the constitutional status of historic preservation grants meet with some disagreement - and we expect that they will - we think that the context of historic preservation of houses of worship provides a rich context for exploring fundamental questions about the relationship between the state and religious institutions. Neither the strong Separationist solution, which would forbid both regulation and subsidy of the historic character of houses of worship, nor the Neutralist's acceptance of regulation and subsidy of religious entities on equal terms with other institutions, tracks the current trajectory of constitutional law. Moreover, neither view captures the dual nature of religious institutions, perhaps best reflected in their structures, which are at once the places in which the defining activity of the faith occurs, and at the same time vital parts of the community's historical and cultural legacy. 